\title{
Pengaruh Sistem Pengendalian Internal Terhadap Kualitas Laporan Keuangan Pemerintah Daerah Kabupaten Manokwari
}

\author{
Etik Wahyuni ${ }^{1}$, Anik Wuriasih ${ }^{2}$ Syarifuddin $^{2}$ \\ ${ }^{1}$ Alumni Program Studi Akuntansi, Universitas Papua \\ ${ }^{2}$ Program Studi Akuntansi, Universitas Papua
}

Received: Januari 2019; Accepted: Februari 2019; Published: Maret 2019

\begin{abstract}
Abstrak
Penelitian ini mengkaji pengaruh beberapa faktor Sistem Pengendalian Internal (pengendalian lingkungan, penilaian risiko, kegiatan pengendalian, informasi dan komunikasi, dan pemantauan) terhadap kualitas laporan keuangan Pemerintah Daerah. Populasi dari penelitian ini adalah mereka yang bekerja di SKPD Kabupaten Manokwari. Sampel dalam penelitian ini adalah kepala dan pegawai bagian akuntansi/keuangan. Penelitian dilakukan terhadap 45 responden sebagai sampel yang didapat dari teknik probabilitas sampling. Data penelitian dikumpulkan dengan menyebarkan kuesioner kepada responden yang terkait. Hasil penelitian menunjukkan bahwa seluruh variabel independen berpengaruh positif terhadap kualitas laporan keuangan Pemerintah Daerah. Hal ini menunjukkan Sistem Pengendalian Internal yang dimiliki Pemerintah Daerah Kabupaten Manokwari sangat baik.
\end{abstract}

Kata kunci: sistem pengendalian internal, kualitas laporan keuangan pemerintah daerah

\begin{abstract}
This study aims to examine the influence of several factors of Internal Control Systems (control environment, risk assessment, control activities, information and communication, and monitoring) on the quality of local government financial statements. The population in this study are all working in SKPD Manokwari. The sample in this study is the head of department and the stafflemployees of the financial part. Our sample are 45 respondents. The samples were selected by using a probability sampling method. Data was collected by distributing questionnaire to the respondents directly concerned. The results show that all independent variables of Internal Control System has a significant effect on the quality of local government financial statements. It then can be concluded that all element factor of Internal Control System is the most effective.
\end{abstract}

Keywords: internal control system, quality of local government financial statement

How to Cite: Wahyuni, E., Wuriasih, A., Syarifuddin. (2019). Pengaruh Sistem Pengendalian Internal Terhadap Kualitas Laporan Keuangan Daerah Kabupaten Manokwari. JFRES: Journal of Fiscal and Regional Economy Studies, 2 (1), 48 - 57.

Corresponding author:

E-mail: akoeanik@gmail.com 


\section{PENDAHULUAN}

Sistem Pengendalian Internal (SPI) di lingkungan instansi pemerintah dikenal sebagai suatu sistem yang diciptakan untuk mendukung upaya agar penyelenggaraan kegiatan pada instansi pemerintahan dapat mencapai tujuannya secara efektif dan efisien, dimana pengelolaan keuangan negara dapat dilaporkan secara andal, asset negara dapat dikelola dengan aman, dan tentunya mendorong ketaatan terhadap peraturan perundang-undangan. SPI dalam penerapannya harus senantiasa memperhatikan norma keadilan dan kepatuhan serta mempertimbangkan ukuran, kompleksitas dan sifat dari tugas serta fungsi instansi pemerintah (Penjelasan umum PP No. 60 Tahun 2008 tentang Sistem Pengendalian Intern Pemerintah).

Adanya tuntutan pemerintahan yang baik (good government) serta undang-undang No 60 tahun 2008 yang mengatur tentang pengendalian internal atas laporan keuangan suatu instansi maka dengan demikian instansi tersebut harus mampu mewujudkan efektivitas, efisiensi serta kualitas laporan keuangan yang dimilikinya. Seperti halnya penelitian yang dilakukan oleh Kartika (2010) bahwasannya sistem pengendalian intern pemerintah memiliki fungsi untuk memberi keyakinan yang memadai bagi tercapainya efektivitas dan efisiensi pencapaian tujuan penyelenggaraan pemerintahan negara, keandalan laporan keuangan, pengamanan asset negara dan ketaatan terhadap undang-undang. Ditambahkan oleh Armando (2013) dalam penelitiannya bahwa sistem pengendalian intern pemerintah terkait dengan laporan keuangan merupakan suatu proses yang didesain untuk memberikan keyakinan yang memadai atas keandalan laporan keuangan yang sesuai dengan Standar Akuntansi Pemerintaha dimana akan menghasilkan laporan keuangan yang mempunyai nilai informasi.

Bentuk dari good government adalah akuntabilitas. Akuntabilitas dapat diartikan sebagai bentuk pertanggungjawaban keberhasilan ataupun kegagalan pelaksanaan misi organisasi dalam mencapai tujuan dan sasaran yang telah ditetapkan sebelumnya melalui suatu media pertanggungjawaban yang dilaksanakan secara periodik. Salah satu bentuk media pertanggungjawaban pemerintah kepada masyarakat adalah melalui laporan keuangan yang melaporkan aktivitas pengelolaan keuangan di institusi pemerintah. Dengan demikian untuk mendapatkan laporan keuangan yang berkualitas harus ditunjang dengan sistem pengendalian internal yang memadai.Penelitian Kartika (2010) membuktikan bahwa sistem pengendalian internal pemerintah berpengaruh terhadap kualitas laporan keuangan.Penelitian Armado (2013) , Bahtiar (2013) serta Herawati (2014) membuktikan bahwa sistem pengendalian intern pemerintah berpengaruh positif signifikan terhadap nilai laporan keuangan. Begitu pula penelitian yang dilakukan oleh Sutawan dkk (2015) yang menunjukkan bahwa stress kerja, motivasi dan sistem pengendalian internal memiliki efek yang kuat terhadap kualitas laporan keuangan.

Di dalam suatu instansi terdapat unsur SPI yaitu lingkungan pengendalian, dimana lingkungan pengendalian merupakan pondasi dasar yang mendasari suatu sistem pengendalian intern pemerintah.Apabila lingkungan pengendalian menunjukkan kondisi yang baik, maka dapat memberi pengaruh yang cukup baik bagi suatu organisasi, namun sebaliknya apabila lingkungan pengendalian jelek, mengindikasikan bahwa organisasi tersebut tidak sehat.Di dalam SPI terdapat pula unsur penilaian risiko untuk pelaporan keuangan yang mengharuskan manajemen melakukan pengidentifikasian dan analisis risiko-risiko yang relevan dalam penyusunan laporan yang sesuai dengan prinsipprinsip akuntansi yang berlaku umum (GAAP).Kegiatan pengendalian juga merupakan unsur SPI dimana setiap prosedur dan kebijakan yang dibuat oleh manajemen harus dipastikan ada petunjuk pelaksanaan di dalamnya, sehingga memudahkan pegawai untuk mengikuti kebijakan yang telah dibuat tersebut. Sedangkan informasi dan komunikasi harus disajikan dalam suatu bentuk dan sarana tertentu serta tepat waktu yang diselenggarakan secara efektif sehingga memungkinkan pimpinan instansi pemerintah melaksanakan pengendalian dan tanggungjawabnya, sehingga dapat dikatakan semakin baik penerapan sistem pengendalian intern maka akan semakin baik pula nilai informasi laporan keuangan yang didapatkan. Selain keempat unsur tersebut terdapat unsur pemantauan yang berfungsi untuk mengambil tindakan korektif, yaitu apabila ditemukan adanya penyimpangan, kekeliruan, serta pemborosan dapat segera diperbaiki sehingga laporan keuangan yang dihasilkan berkualitas.

Untuk dapat bermanfaat bagi para penggunanya, laporan keuangan harus memiliki empat karakteristik kualitatif, berdasarkan SAP (2010) keempat karakteristik tersebut merupakan 
persyaratan normatif yang dikehendaki. Karakteristik tersebut yaitu dapat dipahami, relevan, keandalan dan dapat diperbandingkan.Laporan keuangan harus menggunakan bahasa dan istilah yang dapat dipahami oleh para penggunanya agar tidak terjadi inteprestasi yang salah atas laporan keuangan. Laporan keuangan harus relevan untuk memenuhi kebutuhan pengguna dalam proses pengambilan keputusan. Laporan keuangan yang relevan adalah laporan keuangan yang dapat mempengaruhi keputusan ekonomi pengguna dengan membantu mereka untuk mengevaluasi peristiwa masa lalu, masa kini atau masa depan, serta menegaskan atau mengoreksi hasil evaluasi mereka di masa lalu. Laporan keuangan juga harus disajikan secara jujur dan wajar, bebas dari bias dan tidak menyesatkan sehingga dapat diandalkan. Selain itu, laporan keuangan harus lengkap dan netral, tidak memihak kepada siapapun.Kemudian, laporan keuangan harus dapat dibandingkan antar instansi agar pengguna dapat mengidentifikasi trend posisi dan kinerja keuangannya.

Pemerintah Daerah selaku pihak yang diberikan mandat oleh rakyat untuk mengelola dan menyelenggarakan pemerintahan di daerah harus mempertanggungjawabkan kinerjanya kepada rakyat. Dalam menjalankan pemerintahan yang efektif dan efisien perlu ditunjang oleh sistem pengawasan yang memadai guna mencegah tindakan-tindakan penyelewengan yang tidak diinginkan khususnya yang berkaitan dengan masalah keuangan, baik itu pengawasan dari luar maupun dari dalam organisasi itu sendiri.

\section{METODE PENELITIAN}

Penelitian ini merupakan penelitian deskriptif kuantitatif, yang bertujuan untuk mendapatkan bukti serta menjelaskan hubungan antara elemen Sistem Pengendalian Internal yaitu pengendalian lingkungan, penilaian risiko, kegiatan pengendalian, informasi dan komunikasi, dan pemantauan terhadap kualitas laporan keuangan Pemerintah Daerah. Penelitian ini juga bermaksud untuk mendapatkan kejelasan fenomena yang terjadi secara empiris dan berusaha untuk mendapatkan jawaban hubungan kausal antar variabel melalui pengujian hipotesis.

Penelitian dilakukan di Satuan Kerja Perangkat Daerah (SKPD) Kabupaten Manokwari, sedangkan sumber data penelitian yang digunakan dalam penelitian ini adalah data primer. Data dikumpulkan melalui metode angket, yaitu dengan menyebarkan kuesioner kepada responden yang menjadi kepala departemen serta staf bagian akuntansi/keuangan, yakni sebanyak 45 responden. Pengambilan sampel dalam penelitian ini menggunakan metode purposive sampling.

Model dan alat analisis Model analisa data yang dipergunakan dalam penelitian ini adalah model analisis regresi linear berganda. Analisis regresi linear berganda adalah hubungan antara dua atau lebih variable independen $(\mathrm{X} 1, \mathrm{X} 2, \ldots \mathrm{Xn})$ dengan variabel dependen (Y). Pada penelitian ini analisis data dilakuakan dengan menggunakan bantuan program aplikasi SPSS Versi 22 for Windows. Persamaan Linear berganda :

$$
\mathrm{Y}=\mathrm{a}+\beta 1 \mathrm{X} 1+\underset{5 \mathrm{X} 5}{\beta 2 \mathrm{X} 2}+\beta 3 \mathrm{X} 3+\beta 4 \mathrm{X} 4+\beta
$$

Keterangan :

$\mathrm{Y}=$ Kualitas Laporan Keuangan Pemerintah Daerah

$\mathrm{X} 1=$ Pengendalian Lingkungan

$\mathrm{X} 2$ = Penilaian Risiko

$\mathrm{X} 3=$ Kegiatan Pengendalian

$\mathrm{X} 4=$ Informasi dan Komunikasi

$\mathrm{X} 5=$ Pemantauan

a $\quad=$ Konstanta (nilai $Y^{\prime}$ apabila X1, X2...Xn $=0$ )

$\beta=$ Koefisien regresi (nilai peningkatan ataupun penurunan)

$\mathrm{e} \quad=$ Error

Teknik Analisis yang digunakan memakai uji validitas, uji reliabilitas dan uji normalitas. Uji validitas akan menggambarkan bahwa pertanyaan yang digunakan mampu untuk mengungkapkan sesuatu yang akan diukur (valid). Suatu pertanyaan yang digunakan dikatakan valid jika skor pertanyaan tersebut berkorelasi secara signifikan dengan skor totalnya, batas minimum $r=0,3$ apabila korelasi antara skor butir pertanyaan dengan skor total kurang dari 0,3 maka dinyatakan tidak valid dan harus dibuang atau dikeluarkan. Uji reliabilitas adalah data untuk mengukur suatu kuisioner yang merupakan indikator dari variabel atau konstruk. Suatu kuisioner dikatakan reliabel atau handal jika jawaban seseorang terhadap pernyataan adalah konsisten atau stabil dari waktu ke waktu. Tinggi rendahnya reliabilitas secara empiris ditujukan oleh suatu angka yang disebut koefisien reliabilitas. Sedangkan uji 
normalitas merupakan salah satu asumsi yang harus dipenuhi dalam melakukan analisis regresi linear berganda.

Pengujian hipotesis bertujuan untuk menguji ada tidaknya pengaruh dari variabel independen terhadap dependen. Untuk mengetahui diterima atau tidak hipotesis yang diajukan dalam penelitian ini, dilakukan analisis data dengan menggunakan uji $\mathrm{t}$. Uji $\mathrm{t}$ digunakan untuk membandingkan antara nilai $\mathrm{t} h$ dengan nilai $\mathrm{t}$ dengan kaidah keputusan yaitu jika nilai $\mathrm{t} h \geq \mathrm{t}$, maka Ho ditolak sehingga dapat disimpulkan bahwa variabel independen berpengaruh terhadap variabel dependen, begitupun sebaliknya (Ghozali, 2103).

\section{Sistem Pengendalian Internal}

Sistem pengendalian intern menurut Peraturan Pemerintah No. 60 Tahun 2008 tentang Sitem Pengendalian Intern Pemerintah adalah sebagai berikut :" Sistem pengendalian intern adalah proses yang integral pada tindakan dan kegiatan yang dilakukan secara terus menerus oleh pimpinan dan seluruh pegawai untuk memberikan keyakinan memadai atas tercapainya tujuan organisasi melalui kegiatan yang efektif dan efisien, keandalan pelaporan keuangan, pengamanan asset negara, dan ketaatan terhadap peraturan perundangundangan ".

Unsur-unsur sistem pengendalian internal pemerintah menurut Peraturan Pemerintah No.60 Tahun 2008 adalah sebagai berikut :

1. Lingkungan pengendalian

Lingkungan Pengendalian menggambarkan keseluruhan sikap organisasi yang mempengaruhi kesadaran dan tindakan personel organisasi mengenai pengendalian (Bastian, 2011).

2. Penilaian risiko

Menurut Bastian (2011) untuk tujuan pelaporan keuangan adalah proses identifikasi, analisis, dan pengelolaan risiko entitas yang berkaitan dengan penyusunan laporan keuangan sesuai dengan prinsip akuntansi yang berlaku umum. Diawali dengan penetapan maksud dan tujuan instansi pemerintah yang jelas dan konsisten pada tingkat kegiatan.Selanjutnya instansi pemerintah mengidentifikasi secara efisien dan efektif risiko yang dapat menghambat pencapaian tujuan tersebut, baik yang bersumber dari dalam maupun luar instansi.

3. Kegiatan pengendalian
Kegiatan pengedalian adalah kebijakan dan prosedur yang dibuat untuk memastikan pelaksanaan petunjuk yang dibuat oleh manajemen (Bastian, 2011).Penelitian Herawati (2014) menunjukkan bahwa kegiatan pengendalian berpengaruh namun tidak signifikan terhadap kualitas laporan keuangan.

4. Informasi dan komunikasi

Kebijakan dan prosedur pengendalian yang berkaitan dengan sistem akuntansi adalah bahwa transaksi dilaksanakan dengan mencegah terjadinya salah saji potensial terhadap pernyataan manajemen dalam laporan keuangan (Bastian, 2011).Instansi pemerintah harus memiliki informasi yang relevan dan dapat diandalkan baik informasi keuangan maupun non keuangan yang berhubungan dengan peristiwa-peristiwa eksternal dan internal, yang menyediakan dan memanfaatkan berbagai bentuk dan sarana komunikasi serta mengelola, mengembangkan dan memperbaharui sistem informasi secara terus menerus.

5. Pemantauan

Proses penilaian kinerja dari stuktur pengendalian internal sepanjang waktu (Bastian, 2011). Dilaksanakan melalui pemantauan berkelanjutan, evaluasi terpisah, dan tindak lanjut rekomendasi hasil audit dan review lainnya.

\section{Kualitas Laporan Keuangan}

Kualitas laporan keuangan adalah ukuran-ukuran normatif yang perlu diwujudkan dalam informasi akuntansi sehingga dapat memenuhi tujuannya (PP No. 71 tahun 2010). Terdapat empat karakteristik kualitatif utama laporan keuangan yang harus dipenuhi untuk melihat kualitas laporan keuangan sebagaimana dijelaskan pada kerangka dasar Standar Akuntansi Pemerintah Nomor 71 tahun 2010. Keempat karakteristik tersebut adalah sebagai berikut

1. Relevan

Laporan keuangan bisa dikatakan relevan apabila informasi yang termuat didalamnya dapat mempengaruhi keputusan pengguna dengan membantu mereka mengevaluasi peristiwa masa lalu dan masa kini. Informasi yang relevan meliputi :

a. Memiliki manfaat umpan balik (feedback value)

Informasi memungkinkan pengguna untuk menegaskan atau mengoreksi ekspektasi mereka di masa lalu. 
b. Memiliki manfaat prediktif (predictive value)

Informasi dapat membantu pengguna untuk memprediksi masa yang akan datang berdasarkan hasil masa lalu dan kejadian masa kini.

c. Tepat waktu

Informasi disajikan tepat waktu sehingga dapat berpengaruh dan berguna dalam pengambilan keputusan.

d. Lengkap

Informasi akuntansi keuangan pemerintah disajikan selengkap mungkin mencakup semua informasi akuntansi yang dapat mempengaruhi pengambilan keputusan dengan memperhatikan kendala yang ada.

2. Andal atau dapat dipercaya

Informasi dalam laporan keuangan bebas dari pengertian yang menyesatkan dan kesalahan material, menyajikan setiap fakta secara jujur, serta dapat diverifikasi. Informasi yang andal memenuhi karakteristik :

a. Penyajian jujur

Informasi menggambarkan dengan jujur transaksi serta peristiwa lainnya yang seharusnya disajikan atau secara wajar dapat diharapkan.

b. Dapat diverifikasi

Informasi yang disajikan dalam laporan keuangan dapat diuji, dan apabila pengujian dilakukan lebih dari sekali oleh pihak yang berbeda, hasilnya tetap menunjukkan kesimpulan yang tidak berbeda jauh.

\section{c. Netralitas}

Informasi diarahkan pada kebutuhan umum dan tidak berpihak pada kebutuhan pihak tertentu.

\section{Dapat dibandingkan}

Informasi yang termuat dalam laporan keuangan akan lebih berguna jika dapat dibandingkan dengan laporan keuangan periode sebelumnya atau laporan keuangan entitas pelaporan lain pada umumnya. Perbandingan dapat dilakukan secara internal dan eksternal. Perbandingan secara internal dapat dilakukan bila suatu entitas menerapkan kebijakan akuntansi yang sama dari tahun ke tahun. Perbandingan secara eksternal dapat dilakukan bila entitas yang diperbandingkan menerapkan kebijakan akuntansi yang sama.

4. Dapat dipahami

Informasi yang disajikan dalam laporan keuangan dapat dipahami oleh pengguna dan dinyatakan dalam bentuk serta istilah yang disesuaikan dengan batas pemahaman para pengguna.

\section{HASIL DAN PEMBAHASAN}

Data dalam penelitian ini meliputi kualitas laporan keuangan Pemerintah Daerah (Y) sebagai variabel independen dan pengendalian lingkungan, penilaian risiko, pelaksanaan pengendalian, informasi dan komunikasi, dan pemantauan sebagai variabel independen. Adapun deskripsi data penelitiandisajikan pada Tabel 1.

Tabel 1. Statistik Deskriptif $(\mathrm{N}=45)$

\begin{tabular}{lrrrrrr}
\hline & N & Min & Max & Mean & $\begin{array}{c}\text { Std. } \\
\text { Deviation }\end{array}$ & Variance \\
\hline R & 45 & 1.0 & 45.0 & 23.000 & 13.1339 & 127.500 \\
Lingkungan & 45 & 13.0 & 35.0 & 28.267 & 5.1186 & 26.200 \\
Resiko & 45 & 2.0 & 8.0 & 6.267 & 2.1256 & 4.518 \\
Kegiatan & 45 & 15.0 & 35.0 & 27.667 & 4.8570 & 23.591 \\
InfoKom & 45 & 2.0 & 8.0 & 6.133 & 2.2823 & 5.209 \\
Pemantauan & 45 & 3.0 & 11.0 & 7.844 & 2.3155 & 5.362 \\
Kualitas LK & 45 & 21.0 & 40.0 & 34.778 & 4.9400 & 24.404 \\
Valid N & 45 & & & & & \\
(listwise) & & & & & & \\
\hline Surition
\end{tabular}

\section{Sumber: Data diolah (2018)}

Pada Tabel 1 dapat dilihat bahwa variabel Lingkungan Pengendalian memiliki nilai terendah sebesar 13,00 dan nilai tertinggi sebesar 35,00 dengan nilai rata-rata sebesar 28,27 dan standar deviasinya sebesar 5,12. Variabel Penilaian Risiko memiliki nilai terendah sebesar 2,00 dan nilai tertinggi sebesar 8,00 dengan nilai rata-rata sebesar 6,27 dan standar deviasinya sebesar 2,13. Variabel Kegiatan Pengendalian memiliki nilai terendah sebesar 15,00 dan nilai tertinggi sebesar 35,00 dengan nilai rata-rata sebesar 27,67 dan standar deviasinya sebesar 4,86. Variabel Informasi dan Komunikasi memiliki nilai terendah sebesar 2,00 dan nilai 
tertinggi sebesar 8,00 dengan nilai rata-rata sebesar 6,13 dan standar deviasinya sebesar 2,28. Variabel Pemantauan memiliki nilai terendah sebesar 3,00 dan nilai tertinggi sebsar 11,00 dengan nilai rata-rata sebesar 7,84 dan standar deviasinya sebesar 2,32. Variabel Kualitas Laporan Keuangan (Y) memiliki nilai terendah sebesar 21,00 dan nilai tertinggi sebesar 40,00 dengan nilai rata-rata sebesar 34,78 dan standar deviasinya sebesar 4,94.

Tabel 2 menunjukkan bahwa nilai signifikansi sebesar 0,824 lebih besar dari 0,05, sehingga dapat disimpulkan bahwa data berdistribusi normal.

Tabel 3 menunjukkan bahwa semua variabel independen memiliki nilai VIF di bawah 10 dan nilai tolerance diatas 0,10 maka dapat disimpulkan bahwa tidak terdapat multikoleniaritas antar variabel independen dalam model regresi.

Pada Tabel 4 dapat dilihat bahwa nilai signifikansi lingkungan pengendalian sebesar 0,787 , nilai signifikansi penilaian risiko sebesar 0,940 , nilai signifikansi kegiatan pengendalian sebesar 452, nilai signifikansi informasi dan komunikasi sebesar 0,170 serta nilai signifikansi pemantauan sebesar 0,077 . Hal ini menunjukkan bahwa nilai signifikansi lebih besar dari 0,05, maka dapat disimpulkan bahwa tidak terjadi heterokedastisitas.

Tabel 2. Hasil1Uji Normalitas

\begin{tabular}{|c|c|c|c|}
\hline \multicolumn{4}{|c|}{ One-Sample Kolmogorov-Smirnov Test } \\
\hline & & \multicolumn{2}{|c|}{ Unstandardized Residual } \\
\hline $\mathrm{N}$ & & & 45 \\
\hline \multirow[t]{2}{*}{ Normal Parameters ${ }^{\mathrm{a}, \mathrm{b}}$} & Mean & & .0000000 \\
\hline & Std. Deviation & & 64042209 \\
\hline \multirow[t]{3}{*}{ Most Extreme Differences } & Absolute & & .094 \\
\hline & Positive & & .070 \\
\hline & Negative & & -.094 \\
\hline Kolmogorov-Smirnov Z & & & .629 \\
\hline Asymp. Sig. (2-tailed) & & & .824 \\
\hline \multicolumn{4}{|l|}{$\begin{array}{l}\text { a. Test distribution is Normal. } \\
\text { b. Calculated from data. }\end{array}$} \\
\hline \multicolumn{4}{|l|}{ Sumber: Data diolah (2018) } \\
\hline \multicolumn{4}{|l|}{ Tabel 3. Hasil Uji Multikolinearitas } \\
\hline Model & \multicolumn{3}{|c|}{ Colinearity Statistis } \\
\hline & Tolerance & VIF & \\
\hline Pengendalian Lingkungan & 0,141 & 7,109 & \\
\hline Penilaian Risiko & 0,388 & 2,579 & \\
\hline Kegiatan Pengendalian & 0,121 & 8,276 & \\
\hline Informasi dan Komunikasi & 0,337 & 2,963 & \\
\hline Pemantauan & 0,206 & 4,864 & \\
\hline
\end{tabular}

Sumber: Data diolah (2018)

Tabel 4. Hasil Uji Heteroskedastisitas

\begin{tabular}{|c|c|c|c|c|c|c|}
\hline \multicolumn{7}{|c|}{ Coefficients $^{\mathrm{a}}$} \\
\hline & \multirow[t]{2}{*}{ Model } & \multicolumn{2}{|c|}{$\begin{array}{c}\text { Unstandardized } \\
\text { Coefficients }\end{array}$} & \multirow{2}{*}{$\begin{array}{c}\begin{array}{c}\text { Standardized } \\
\text { Coefficients }\end{array} \\
\text { Beta }\end{array}$} & \multirow[t]{2}{*}{$\mathbf{t}$} & \multirow[t]{2}{*}{ Sig. } \\
\hline & & B & Std. Error & & & \\
\hline \multirow[t]{6}{*}{1} & (Constant) & -0.114 & 0.417 & & -0.272 & 0.787 \\
\hline & Pengendalian Lingkungan & -0.002 & 0.03 & -0.029 & -0.076 & 0.940 \\
\hline & Penilaian Risiko & 0.033 & 0.043 & 0.174 & 0.759 & 0.452 \\
\hline & Kegiatan Pengendalian & 0.058 & 0.034 & 0.709 & 1.723 & 0.093 \\
\hline & Informasi dan Komunikasi & -0.06 & 0.043 & -0.344 & -1.398 & 0.170 \\
\hline & Pemantauan & -0.098 & 0.054 & -0.572 & -1.814 & 0.077 \\
\hline
\end{tabular}

a. Dependent Variable: RES2

Sumber: Data diolah (2018)

Uji Statistik (Uji F, Uji t dan Koefisien Determinasi)

Berdasarkan Tabel 5 dapat diketahui $\mathrm{F}_{\text {hitung }}$ yaitu sebesar 456,313. Adapun $F_{\text {tabel }}$ pada tingkat signifikansi $5 \%$ dan degree of freedom (df) sebesar k-1 (5-1) dan tingkat derajat bebas penyebut (df2) sebesar n-k (45-4=41) adalah sebesar 2,60. Jika kedua nilai dibandingkan 
maka nilai $\mathrm{F}_{\text {hitung }}$ lebih besar dari $\mathrm{F}_{\text {tabel }}(456,313$ > 2,60) serta nilai probabilitas $F_{\text {hitung }}$ juga lebih kecil dari nilai $0,005(0,00<0,05)$ sehingga terdapat pengaruh secara simultan antara variabel independen terhadap variabel dependen. Hasil pengujian hipotesis secara parsial (Tabel 6) setiap variabel independen sebagai berikut :

1. Variabel Lingkungan Pengendalian mempunyai nilai $t_{\text {hitung }}$ sebesar 9,344 dengan nilai Signifikansi sebesar 0,000. Oleh karena nilai signifikansi lebih kecil dari 0,05 maka H1 diterima, sehingga dapat disimpulkan bahwa variabel Lingkungan pengendalian berpengaruh terhadap Kualitas Laporan Keuangan Pemerintah Daerah Kabupaten Manokwari.

2. Variabel Penilaian Risiko mempunyai nilai $\mathrm{t}_{\text {hitung }}$ Sebesar 2,561 dengan nilai Signifikansi sebesar 0,014. Oleh karena nilai Signifikansi lebih kecil dari 0,05 maka H2 diterima, sehingga dapat disimpulkan bahwa variabel Penilaian Risiko berpengaruh terhadap Kualitas Laporan Keuangan Pemerintah Daerah Kabupaten Manokwari.

3. Variabel Kegiatan pengendalian memiliki nilai $t_{\text {hitung }}$ sebesar 3,368 dengan nilai Signifikansi sebesar 0,002. Oleh karena nilai Signifikansi jauh lebih kecil dari 0,05 maka H3 diterima, sehingga dapat disimpulkan bahwa variabel Kegiatan Pengendalian berpengaruh terhadap Kualitas Laporan Keuangan Pemerintah Daerah Kabupaten Manokwari. Kegiatan pengendalian dilakukan sebagai pengendalian dari kegiatan organisasi yang berkaitan dengan tujuan organisasi, sehingga pentingnya pengendalian secara terus menerus atas kegiatan yang dilakukan guna mencapai tujuan yang telah ditetapkan.

4. Variabel Informasi dan Komunikasi memiliki nilai $t_{\text {hitung }}$ sebesar 3,002 dengan nilai Signifikansi sebesar 0,005. Oleh karena nilai Signifikansi lebih kecil dari 0,05 maka H4 diterima, sehingga dapat disimpulkan bahwa variabel Informasi dan Komunikasi berpengaruh terhadap Kualitas Laporan Keuangan pemerintah Daerah Kabupaten Manokwari.

5. Variabel pemantauan memiliki nilai $t_{\text {hitung }}$ sebesar 3,261 dengan nilai Signifikansi sebesar 0,002. Oleh karena nilai Signifikansi lebih kecil dari 0,05 maka H5 diterima, sehingga dapat disimpulkan bahwa gan Pemerintah Daerah Kabupaten Manokwari.

Tabel 5. Hasil Uji Statistik Uji F

\begin{tabular}{|c|c|c|c|c|c|c|}
\hline \multicolumn{7}{|c|}{$\overline{\text { ANOVA }^{\mathrm{a}}}$} \\
\hline & Model & $\begin{array}{l}\text { Sum of } \\
\text { Squares }\end{array}$ & df & Mean Square & $\mathbf{F}$ & Sig. \\
\hline \multirow[t]{3}{*}{1} & Regression & 1055.732 & 5 & 211.146 & 456.313 & $.000^{\mathrm{b}}$ \\
\hline & Residual & 18.046 & 39 & .463 & & \\
\hline & Total & 1073.778 & 44 & & & \\
\hline & ependent Variable: Kua & & & & & \\
\hline
\end{tabular}

Sumber: Data diolah (2018)

Tabel 6. Hasil Uji Hipotesis Uji t

\begin{tabular}{ccc}
\hline Variabel Independen & t hitung & sig \\
\hline Lingkungan Pengendalian (x1) & 9,344 & 0,000 \\
Penilaian Risiko (x2) & 2,561 & 0,014 \\
Kegiatan Pengendalian (x3) & 3,368 & 0,002 \\
Informasi dan Komunikasi (x4) & 3,002 & 0,005 \\
Pemantauan (x5) & 3,261 & 0,002 \\
\hline
\end{tabular}

Sumber: Data diolah (2018)

Tabel 7. Hasil Uji Koefisien Determinasi Model Summary $^{\mathrm{b}}$

\begin{tabular}{lccr}
\multicolumn{4}{c}{ Model Summary } \\
\hline \multicolumn{1}{c}{ Rodel } & R Square & $\begin{array}{c}\text { Adjusted R } \\
\text { Square }\end{array}$ & Std. Error of the Estimate \\
\hline 1 & $.992^{\text {a }}$ & .983 & .981 \\
\hline $\begin{array}{l}\text { a. Predictors: (Constant), Pemantauan, Risiko, InfoKom, Lingkungan, Kegiatan } \\
\text { b. Dependent Variable: KualitasLK }\end{array}$
\end{tabular}


Tabel 7 menunjukkan bahwa nilai adjusted $\mathrm{R}$ Square sebesar 0,981 artinya sebesar 98,1\% variabel dependen yaitu Kualitas Laporan Keuangan dapat dijelaskan oleh variabel independennya yaitu Lingkungaan pengendalian, Penilaian Risiko, Kegiatan pengendalian, Informasi dan Komunikasi serta Pemantauan. Sedangkan sisanya $1,9 \%$ dijelaskan oleh variabel lain diluar penelitian ini.

\section{Analisis Regresi Berganda}

Dari Tabel 8 diperoleh bentuk persamaan regresi sebagai berikut :

$$
\begin{aligned}
\mathrm{Y}= & 9.843+0.499 \mathrm{X}_{1}+0.189 \mathrm{X}_{2}+0.205 \mathrm{X}_{3}+0.232 \mathrm{X}_{4} \\
& +0.319 \mathrm{X}_{5}+\mathrm{e}
\end{aligned}
$$

Bentuk persamaan diatas memberikan gambaran bahwa :

1. Konstanta sebesar 9,843 menyatakan bahwa jika Variabel bebas dianggap konstan, maka rata-rata Kualitas Laporan Keuangan Pemerintah Daerah Kabupaten Manokwari adalah sebesar 9,843.

2. Lingkungan Pengendalian (x1) mempunyai nilai koefisien regresi sebesar 0,499 dan bernilai positif, yang berarti apabila Variabel Lingkuangan Pengendalian bertambah satu satuan maka Kualitas Laporan Keuangan akan bertambah sebesar 0,499.

3. Penilaian Risiko (x2) mempunyai nilai koefisien regresi sebesar 0,198 dan bernilai positif, yang berarti apabila Variabel Penilaian Risiko bertambah satu satuan maka Kualitas Laporan Keuangan bertambah sebesar 0,198.

4. Kegiatan Pengendalian (x3) mempunyai nilai koefisien regresi sebesar 0,205 dan bernilai positif, yang berarrti apabila Variabel Kegiatan Pengendalian bertambah satu satuan maka Kualitas Laporan Keuangan akan bertambah sebesar 0,205.

5. Informasi dan Komunikasi (x4) mempunyai nilai koefisien regresi sebesar 0,232 dan bernilai positif, yang berarti apabila Variabel Informasi dan Komunikasi berkurang satu satuan maka Kualitas Laporan Keuangan akan berkurang sebesar 0,232 .

6. Pemantauan (x5) mempunyai nilai koefisien regresi sebesar 0,319 dan bernilai positif, yang berarti apabila Variabel Pemantauan berkurang satu satuan maka Kualitas Laporan Keuangan akan berkurang sebesar 0,319.

Tabel 8. Hasil Analisis Regresi Berganda

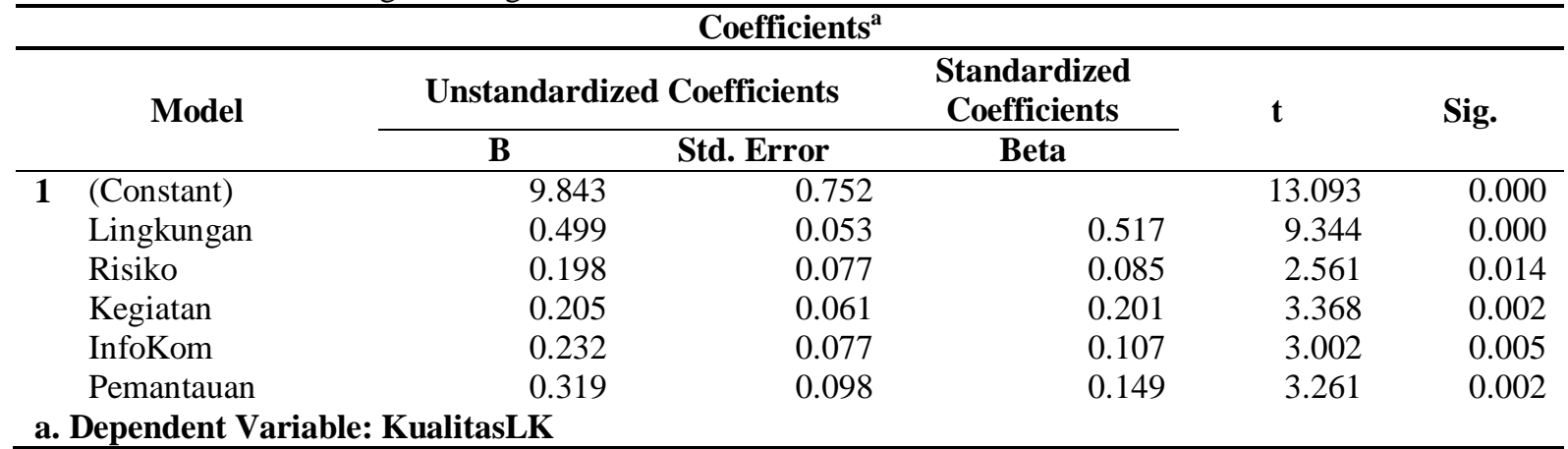

Sumber: Data diolah (2018)

\section{Pengaruh Pengendalian Lingkungan terhadap Kualitas Laporan Keuangan Pemerintah Daerah}

Hasil regresi menunjukkan menunjukkan bahwa variabel pengendalian lingkungan memiliki nilai probabilitas 0,000 lebih kecil dari 0,05, sehingga H1 diterima. Hal ini berarti bahwa pengendalian lingkungan sebagai pondasi dasar dalam sistem pengendalian internal telah mencerminkan keadaan lingkungan yang baik sehingga dapat mempengaruhi personel organisasi untuk melakukan tindakan yang baik. Setiap personel akan melakukan tindakan yang baik sehingga dapat mencegah terjadinya tindakan penyimpangan yang tidak diinginkan oleh organisasi. Hal ini tentu membuat laporan keuangan yang di hasilkan akan lebih berkualitas. Penelitian ini konsisten dengan penelitian Herawati (2014) yang melakukan penelitian secara parsial bahwa lingkungan pengendalian berpengaruh signifikan terhadap kualitas laporan keuangan.

\section{Pengaruh Penilaian Risiko terhadap Kualitas Laporan Keuangan Pemerintah Daerah}

Hasil regresi menunjukkan bahwa variabel penilaian risiko memiliki nilai probabilitas 0,014 lebih kecil dari 0,05 sehingga $\mathrm{H} 2$ diterima. Hal ini sejalan dengan penelitian Herawati (2014) 
yang menunjukkan bahwa penilaian risiko berpengaruh signifikan terhadap kualitas laporan keuangan.

Melalui proses penilaian risiko ini, maka setiap entitas dapat mengantisipasi setiap kejadian yang dapat menghambat pencapaian tujuan organisasi, dimana tujuan organisasi tercermin dalam laporan keuangannya. Semakin rendah tingkat risiko yang dihadapi maka organisasi tersebut akan lebih mudah mencapai tujuan yang telah ditetapkan.

\section{Pengaruh Kegiatan Pengendalian terhadap Kualitas Laporan Keuangan Pemerintah Daerah}

Hasil regresi menunjukkan bahwa Variabel Kegiatan pengendalian memiliki nilai probabbilitas 0,002 lebih kecil dari 0,05 sehingga H3 diterima. Penelitian ini tidak konsisten dengan penelitian Tuti Herawati (2014) yang menunjukkan bahwa kegiatan pengendalian berpengaruh namun tidak signifikan terhadap kualitas laporan keuangan.

\section{Pengaruh Informasi dan Komunikasi terhadap Kualitas Laporan Keuangan Pemerintah Daerah}

Hasil regresi menunjukkan bahwa Variabel informasi dan Komunikasi memiliki nilai probabilitas 0,005 jauh lebih kecil dari 0,05 sehingga $\mathrm{H} 4$ diterima. Hal ini sejalan dengan penelitian Herawati (2014) yang menunjukkan bahwa informasi dan komunikasi berpengaruh signifikan terhadap kualitas laporan keuangan.

Setiap organisasi yang yang telah menjalankan informasi dan komunikasi dalam menunjang aktivitas antar personel dalam suatu organisasi maka akan menambah nilai akurasi dari suatu laporan keuangan yang telah dibuatnya. Hal ini dikarenakan suatu laporan keuangan memerlukan banyak informasi dan dalam mendapatkan suatu informasi tersebut diperlukan komunikasi yang memadai sehingga akan menghasilkan laporan keuangan yang lebih baik.

\section{Pengaruh Pemantauan tethadap Kualitas Laporan Keuangan Pemerintah Daerah}

Hasil regresi menunjukkan bahwa Variabel Pemantauan memiliki nilai probabilitas 0,002 lebih kecil dari 0,05 sehingga $\mathrm{H} 5$ diterima. Hal ini tidak konsisten dengan penelitian Herawati (2014) yang membuktikan bahwa pemantauan berpengaruh namun tidak signifikan terhadap kualitas laporan keuangan.
Pemantauan ini dilakukan sebagai bentuk dari adanya tindakan pengawasan pengendalian internal yang telah dilakukan guna meningkatkan sistem akuntansi keuangan daerah yang baik, hal ini harus ditunjang dengan dilakukannya pengawasan secara efektif sehingga mencegah adanya tindakan penyelewengan dalam pelaksanaanya.

\section{KESIMPULAN}

Berdasarkan hasil penelitian dan pembahasan yang telah dijelaskan, maka diperoleh kesimpulan sebagai berikut :

1. Variabel Pengandalian Lingkungan, Penilaian Risiko, Kegiatan Pengendalian, Informasi dan Komunikasi serta Pemantauan telah terbukti memiliki pengaruh yang signifikan terhadap Kualitas Laporan Keuangan Pemerintah Daerah Kabupaten manokwari.

2. Variabel Lingkungan Pengendalian, Penilaian Risiko, Kegiatan Pengendalian, Informasi dan Komunikasi serta pemantauan mampu menjelaskan variabel Kualitas Laporan Keuangan sebesar 98,1 \% dan sisanya hanya sebagian kecil yaitu sebesar $1,9 \%$ dijelaskan oleh variabel lain diluar penelitian.

3. Pemerintah yang bertindak dan bertanggungjawab sebagai pembuat laporan keuangan (agen) dalam hal ini adalah Pemerintah Daerah Kabupaten Manokwari telah berupaya menghasilkan laporan keuangan yang berkualitas. Hal ini terlihat dari sistem pengendalian internal yang telah dijalankan dengan baik oleh Pemerintah Daerah Kabupaten Manokwari. Mengacu pada penelitian yang telah dilakukan meununjukkan bahwa lingkungan pengendalian, penilaian risiko, kegiatan pengendalian, informasi dan komunikasi serta pemantauan yang merupakan komponen dari sistem pengendalian internal, sehingga dapat disimpulkan bahwa semakin baik sistem pengendalian internal maka laporan keuangan yang dihasilkan akan semakin berkualitas.

Saran dalam penelitian ini adalah sebagai berikut:

1. Bagi pihak pemerintah diharapkan mampu meningkatkan Sistem Pengendalian Internal di setiap SKPD khususnya pada Pemerintahan Daerah, dikarenakan Sistem Pengendalian Internal terbukti bahwa sangat 
mempengaruhi hasil akhir dari kualitas laporan keuangan.

2. Bagi peneliti selanjutnya diharapkan dapat mengembangkan peneltian yang memiliki topik serupa dengan menambahkan variabel-variabel lain yang dapat mempengaruhi kualitas laporan keuangan yang tidak terdapat dalam penelitian ini.

\section{DAFTAR PUSTAKA}

Armando, Gerry. (2013). Pengaruh Sistem Pengendalian Intern Pemerintah dan Pengawsan Keuangan Daerah terhadap Nilai Informasi Laporan Keuangan Pemerintah (Studi empiris pada satuan kerja perangkat daerah di kota Bukittinggi). Skripsi tidak diterbitkan.Universitas Negeri Padang.

Bastian, Indra. (2011). Akuntansi Sektor Publik. Salemba Empat, Jakarta.

Bahtiar, Erwin. (2013). Pengaruh Sistem Pengendalian Intern terhadap Kualitas Laporan Keuangan (Studi kasus pada PT Bank Mega, Tbk Cabang Gorontalo). skripsi tidak diterbitkan. Universitas Negeri Gorontalo.

Herawati, Tuti. (2014). Pengaruh Sistem Pengendalian Intern terhadap Kualitas Laporan Keuangan (Survey pada Organisasi Perangkat Daerah Pemda
Cianjur). STIE STEMBI Bandung Business School (Vol XI, No. 1 Tahun 2014).

Kartika, Indria. (2013). Pengaruh Sistem Pengendalian Intern Pemerintah (SPIP) terhadap kualitas laporan keuangan dan implikasinya terhadap akuntabilitas keuangan (Penelitian pada Laporan Realisasi Anggaran di Pemerintah Daerah Kabupaten Wilayah Provinsi Jawa Barat). Skripsi tidak diterbitkan.Universitas Indonesia.

Mahmudi. (2010). Manjemen Kinerja Sektor Publik. UPP STIM YKPN, Jakarta

Sukandarrumidi. (2012). Dasar-dasar Penulisan Proposal Penelitian: Petunjuk Praktis untuk Peneliti Pemula. Yogyakarta: Gadjah Mada University Press.

Sugiyono. (2012). Memahami Penelitian Kuantitatif. Alfabeta, Bandung :

Sutawan, I Made Edy. Nyoman Ari Surya Dermawan dan Gede Adi Yuniarta. (2015). Pengaruh Stress Kerja, Motivasi dan Sistem Pengendalian Intern terhadap Kualitas Laporan Keuangan Koperasi (Studi kasus pada koperasi di Kabupaten Buleleng). e-journal SI Ak Universitas Pendidikan Ganesha (Volume 3 No. 1 Tahun 2015). 